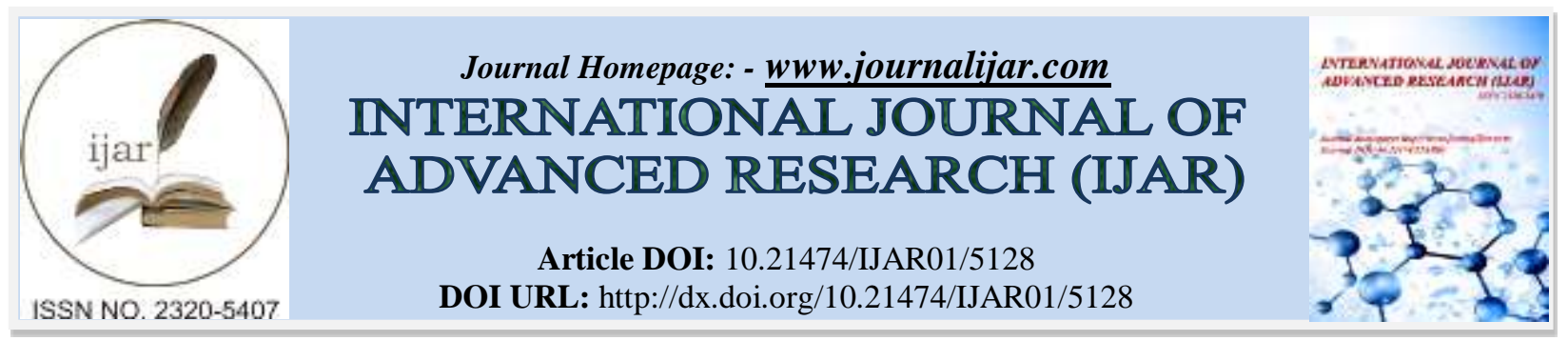

RESEARCH ARTICLE

\title{
SOLID STATE FERMENTATION OF WHEAT STRAW FOR PRODUCTION OF MNP BY $P$. CHRYSOPORIUM MTCC 787.
}

\author{
"Nishant Junnarkar ${ }^{1,2}$ and Neepa Pandhi ${ }^{1}$. \\ 1. Department of Microbiology, Shree M. \& N. Virani Science College, Rajkot, Gujarat, India. 360005. \\ 2. School of Life Sciences, Central university of Gujarat, Gandhinagar, Gujarat, India. 382030.
}

\section{Manuscript Info}

Manuscript History

Received: 10 June 2017

Final Accepted: 12 July 2017

Published: August 2017

Key words:-

Solid State Fermentation, Wheat Straw,

P. chrysosporium, $\mathrm{MnP}$

\begin{abstract}
Solid state fermentation of wheat straw was attempted with $P$. chrysosporium MTCC 787 for production of $\mathrm{MnP}$ at $39^{\circ} \mathrm{C}$. Fermented residue was extracted with $0.2 \mathrm{M}$ sodium tartarate buffer $(\mathrm{pH} 3)$ and was subjected to ammonium sulfate precipitation. Precipitates obtained were subjected to MnP assay, upon dialysis, using MBTH and DMAB as substrate. Optimum $\mathrm{pH}$ and temperature were reported to be $\mathrm{pH} 4.5$ and $30^{\circ} \mathrm{C}$ respectively. $\mathrm{Km}$ and $\mathrm{Vmax}$ of $\mathrm{MnP}$ for $\mathrm{MBTH}$ were found to be $0.05 \mathrm{mM}$ and $25 \mathrm{U} / \mathrm{mg}$, respectively. Enzyme kinetics were also assessed against Reactive Black B (RBB), a widely used textile diazo dye, as substrate. $\mathrm{Km}$ and $\mathrm{Vmax}$ of $\mathrm{MnP}$ for RBB were reported as 0.2 $\mathrm{mM}$ and $7 \mathrm{U} / \mathrm{mg}$, respectively. These findings suggest enormous potential of MnP of $P$. chrysosporium MTCC 787 for its application in treatment of RBB containing wastewater.
\end{abstract}

Copy Right, IJAR, 2017,. All rights reserved.

\section{Introduction:-}

Several white rot fungi have been utilized to produce lignin peroxidase (LiP), manganese peroxidase (MnP), laccase, versatile peroxidase (VP) and other ligninolytic enzymes through solid state fermentation of variety of lignocellulosic substrates (Asgher et al., 2014). Ligninolytic enzymes have found their applications in treatment of pollutant bearing wastewaters due to their ability to act on variety of substrates including textile dyes. Among the synthetic dyes, azo dyes are extensively used in textile, leather, paper, cosmetics, food and pharmaceutical industries (Saratale et al., 2011, Dellamtrice et al., 2017). Azo dyes are the most common synthetic dyes released into the environment during their usage (Saratale et al., 2009). For sulfonated azo dyes, both aromatic sulfonic and azo groups confer to their xenobiotic nature as these are rare among natural products (Junnarkar et al., 2006).

In this paper, we report our studies on white rot fungus $P$. chrysosporium MTCC787 for the production of MnP through solid state fermentation of wheat straw, its characterization assessing its potential to transform textile di-azo dye Reactive Black B.

\section{Materials and Methods:-}

\section{Chemicals and organism:-}

Textile diazo dye Reactive Black B (C. I. Reactive Black 5, $\lambda \max =597 \mathrm{~nm}$ ) was procured from Meghmani Chemicals Ltd., Vatva GIDC, Gujarat, India. 3-methyl-2-benzothiazolinone hydrazone hydrochloride (MBTH), and

Corresponding Author:- Nishant Junnarkar.

Address:- Department of Microbiology, Shree M. \& N. Virani Science College, Rajkot, Gujarat, India. 360005 . 
3-dimethylaminobenzoic acid (DMAB) were purchased from HiMedia Laboratories, India. All the other chemicals and reagents used were of analytical grade.

Phaenerochaete chrysosporium MTCC 787 was procured from Microbial Type Culture Collection and Gene Bank, Institute of Microbial Technology (IMTECH), Chandigarh, India. It was routinely sub-cultured on Malt Extract Agar (MEA, Himedia Lab., India) medium and preserved at $4^{\circ} \mathrm{C}$ on MEA slants till further use.

\section{Solid State Fermentation and preparation of enzyme extract:-}

Solid State Fermentation (SSF) of wheat straw was carried out with P. chrysosporium MTCC 787 as described by Junnarkar et al (2016). P. chrysosporium was cultivated on MEA plates at $39^{\circ} \mathrm{C}$ and agar discs were punched and used as inoculum (6 discs per flask) for solid state fermentative production of $\mathrm{MnP}$ in $250 \mathrm{~mL}$ flasks containing 11.6 $\mathrm{mL}$ Kirk's medium (Junnarkar et al., 2016) and $5 \mathrm{~g}$ wheat straw. Flasks were incubated at $39^{\circ} \mathrm{C}$ till harvested for extraction of MnP. Control flasks were kept in which the culture was not inoculated and were processed as described above.

Flasks were harvested at every $3 \mathrm{~d}$ interval upto $18 \mathrm{~d}$ of incubation $(3,6,9,12,15$ and $18 \mathrm{~d})$ and the contents were suspended in $100 \mathrm{~mL} 0.2 \mathrm{M}$ sodium tartarate buffer (pH 3) and kept under shaking condition for $3 \mathrm{~h}$. Further processing was done as described by Junnarkar et al (2016). The dialyzed samples were then subjected to MnP assay and the enzyme activities were compared with those observed in crude enzyme preparation. Protein estimation was done by the method described by Bradford (1976) using Bovine Serum Albumin as standard.

\section{MnP assay:-}

MnP activity was determined according to Kirk et al. (1986) using MBTH and DMAB as the substrate. The reaction mixture $(\mathrm{RM})$ contained $100 \mathrm{mM}$ succinate lactate buffer (pH 2.0), $25 \mathrm{mM}$ DMAB, $1 \mathrm{mM} \mathrm{MBTH}, 25 \mathrm{mM}$ $\mathrm{MnSO}_{4}$ and $0.1 \mathrm{~mL}$ enzyme and total volume was made $2 \mathrm{~mL}$ with Milli-Q water. The reaction was initiated upon addition of $10 \mathrm{mM} \mathrm{H}_{2} \mathrm{O}_{2}$ and $A_{590}$ was measured after $10 \mathrm{~min}$ incubation at $25^{\circ} \mathrm{C}$. One unit of enzyme was defined as the amount of enzyme required to release $1 \mu \mathrm{mol}$ of oxidized product $\left(\varepsilon=32.9 \mathrm{M}^{-1} \mathrm{~cm}^{-1}\right)$ per min under standard assay conditions.

MnP activities against RBB were also reported by replacing MBTH and DMAB with $0.01 \mathrm{mM}$ RBB in the reaction mixtures and $A_{597}$ was measured after $10 \mathrm{~min}$ to determine the $\mathrm{MnP}$ activity, at $25^{\circ} \mathrm{C}$. One unit of enzyme was defined as the amount of enzyme required to convert $1 \mu \mathrm{mol}$ of $\mathrm{RBB}\left(\varepsilon=35550 \mathrm{M}^{-1} \mathrm{~cm}^{-1}\right)$ into product per min under standard assay conditions.

All the assays were performed in triplicates and mean values of specific activities of LiP and MnP were reported as $\mathrm{U} \mathrm{mg}{ }^{-1}$ of protein. Maximum MnP activity was reported in $6 \mathrm{~d}$ enzyme sample and the dialyzed sample was subjected to further characterization with respect to optimum $\mathrm{pH}$, temperature and substrate concentration.

\section{Effect of pH on MnP activity:-}

$\mathrm{MnP}$ activity was assessed at varying $\mathrm{pH}(\mathrm{pH} 2-6)$ using different buffers $(50 \mathrm{mM})$ in the RM. Buffers used were 50 $\mathrm{mM}$ tartarate buffer ( $\mathrm{pH}$ 2, 2.5 and 3); 50mM succinate lactate buffer ( $\mathrm{pH} 3.5,4$ and 4.5); $50 \mathrm{mM}$ citrate buffer (pH 5 and 5.5) and $50 \mathrm{mM}$ phosphate buffer (pH 6).

\section{Effect of temperature on MnP activity:-}

$\mathrm{MnP}$ activity was monitored at different incubation temperature ranging from $15-45^{\circ} \mathrm{C}$, with a $5^{\circ} \mathrm{C}$ increment in the incubation temperature for RM using MBTH-DMAB as the substrate.

\section{Effect of MBTH concentration on MnP activity:-}

To study the effect of substrate concentration, reaction mixtures were prepared having varying concentration of MBTH i.e. $0.2 \mathrm{mM}, 0.4 \mathrm{mM}, 0.6 \mathrm{mM}, 0.8 \mathrm{mM}, 1.0 \mathrm{mM}, 1.4 \mathrm{mM}, 1.8 \mathrm{mM}, 2.2 \mathrm{mM}$ in $2 \mathrm{ml}$ of enzyme reaction mixture. Assay was performed in triplicates and mean specific activity of $\mathrm{MnP}$ was reported.

\section{Effect of RBB concentration on MnP activity:-}

Effect of RBB concentration on MnP was also assessed at varying concentrations of RBB ranging from 0.005-0.1 $\mathrm{mM}$ in the RMs. Km and Vmax of MnP for RBB was then calculated using LB Plot. 


\section{Results \& Discussion:-}

Effect of incubation period on MnP production under SSF conditions:-

Flasks were harvested at an interval of 3 days and $\mathrm{MnP}$ activities were monitored in crude and dialyzed samples. Crude preparations from 3-9d flasks had deep brown coloration, which may be due to the liberation of polyphenols from the lignocellulosic substrate being transformed by the ligninolytic enzyme systems of $P$. chrysosporium MTCC 787. With the increase in incubation period, decrease in intensity of brown color was observed in crude preparations from 12-18d flasks. As shown in Fig 1, the MnP activity increased steadily over time and maximum specific activity was reported after $6 \mathrm{~d}$ incubation $(29.89 \pm 1.07 \mathrm{U} / \mathrm{mg})$. With further incubation, a gradual decline in the $\mathrm{MnP}$ activity was observed. In the dialyzed samples, nearly a 1.5 -fold increase in the activity was observed, which may be attributed to the presence of concentrated enzyme in the dialyzed samples.

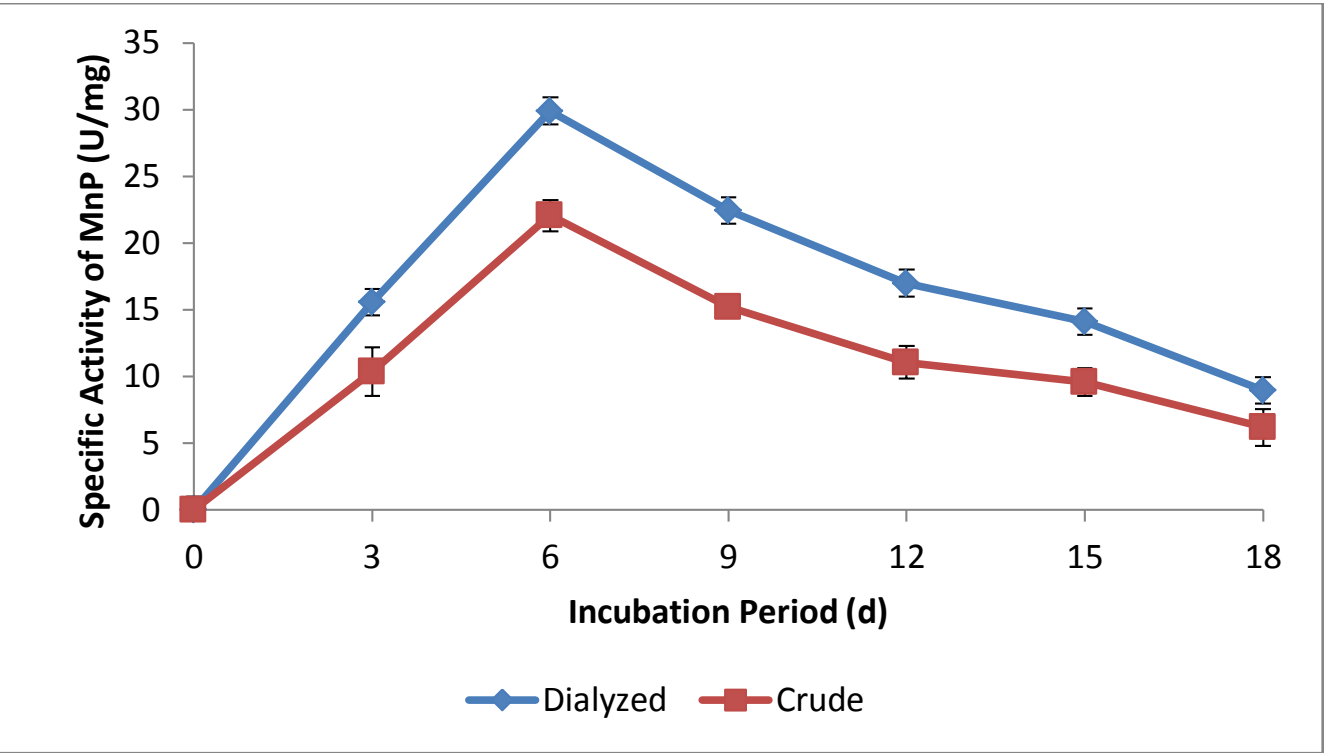

Fig 1:- Effect of incubation period on MnP production by $P$. chrysosporium $\mathrm{MTCC} 787$ at $39^{\circ} \mathrm{C}$ under solid state fermentation conditions.

MnP production by $T$. versicolor was maximally reported on $12^{\text {th }}$ day of incubation during SSF of wheat straw (Arora et al., 2002). For P. chrysosporium, maximum MnP activity was reported between 4-8 days of incubation by several workers (Kerem et al., 1992; Arora et al., 2002; Zeng et al., 2015). Maximum activity of MnP was reported on $7^{\text {th }}$ day of incubation (1293 U/L) during ligninolytic enzyme production by $P$. chrysosporium in fixed bed reactor operating under semi solid-state conditions (Moldes et al., 2003).

\section{Effect of pH on MnP activity:-}

One of the most important parameter for enzyme activity is $\mathrm{pH}$ of the reaction mixture. The MnP activity in the enzyme samples was assessed at different $\mathrm{pH}$ by using various buffers in the reaction mixture; which is shown in Fig 2. Here, the optimum activity of $\mathrm{MnP}$ was reported at $\mathrm{pH} 4.5(31.39 \pm 2.27 \mathrm{U} / \mathrm{mg})$. $\mathrm{pH}$ is critical for heme stability and activity, as it impacts on the ionic form of the enzyme active site residues and thus on the binding to the heme group (Zeng et al., 2015). Three-dimensional structure of enzyme is greatly affected by $\mathrm{pH}$ in reaction mixture. Such structural changes might have been the reason for decreased activity of $\mathrm{MnP}$ at $\mathrm{pH}$ other than its optimum $\mathrm{pH}$. MnP was maximally reported at $\mathrm{pH} 5$ by Sklener et al (2010). Optimum MnP activity of $P$. chrysosporium BKMF-1767 was reported at $\mathrm{pH} 4.5$ by Zeng et al. (2013). 


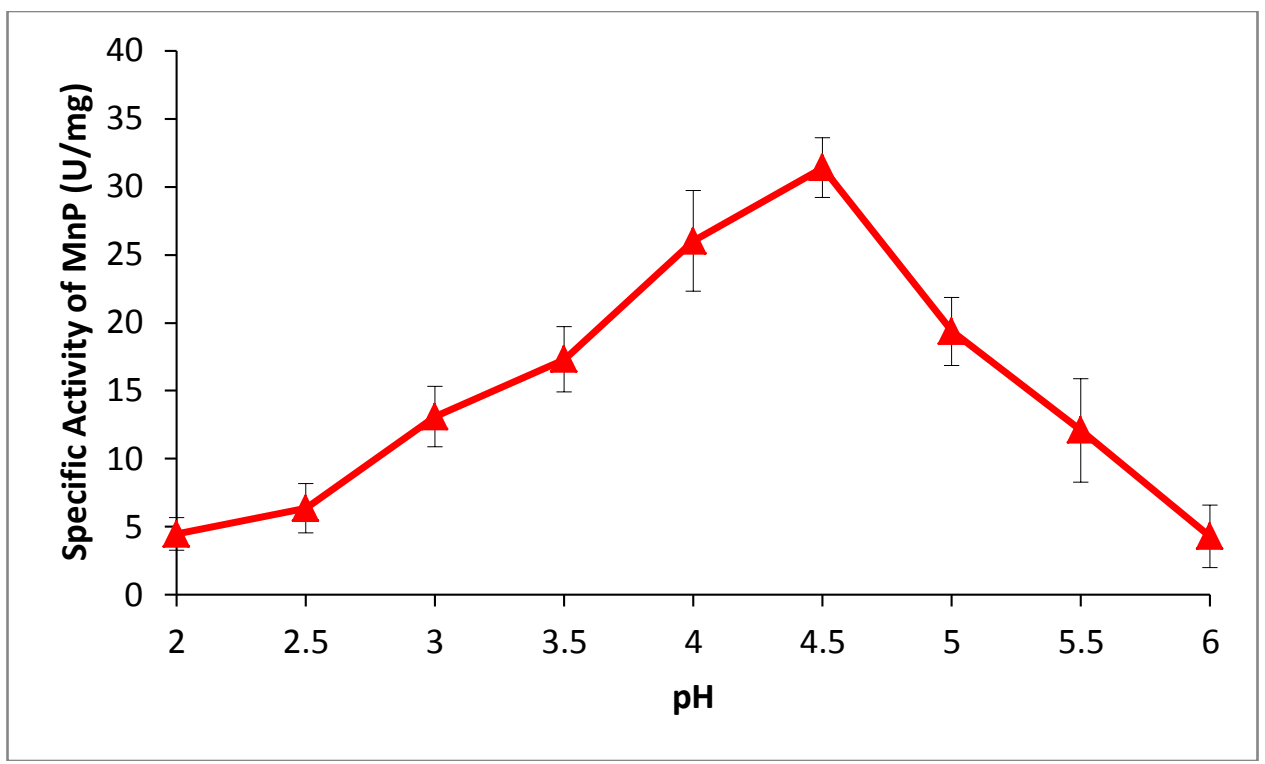

Fig 2:- Effect of pH on MnP activity of P. chrysosporium MTCC787.

Effect of temperature on MnP activity:-

A typical temperature curve for $\mathrm{MnP}$ was observed as shown in Fig 3. Optimum temperature for $\mathrm{MnP}$ of $P$. chrysosporium MTCC 787 was observed at $30^{\circ} \mathrm{C}(32.8 \pm 3.4 \mathrm{U} / \mathrm{mg})$. Comparable results were reported for $\mathrm{MnP}$ of white rot fungal cultures by Wesenberg et al. (2003) and Ghodake et al. (2009).

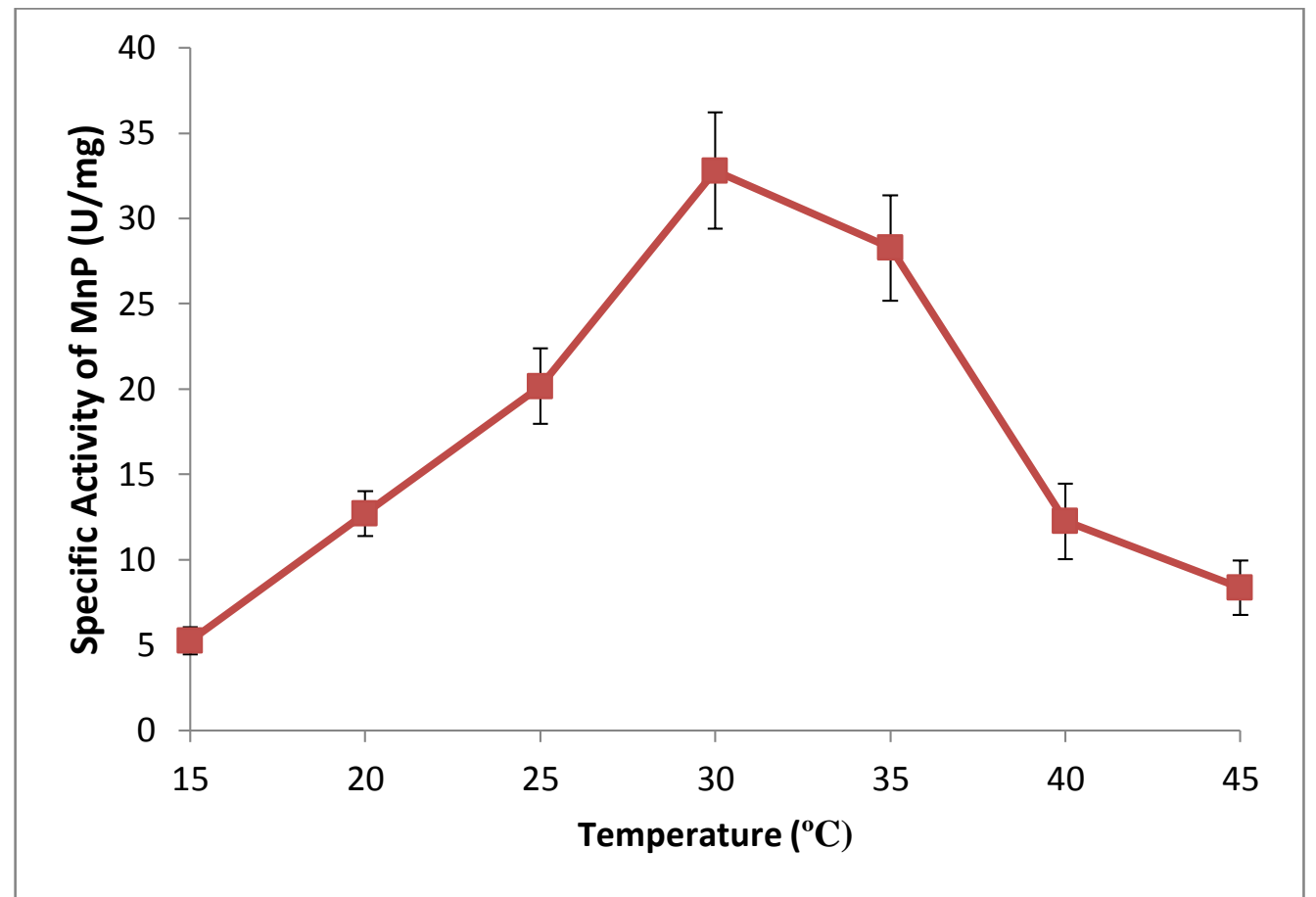

Fig 3:- Effect of temperature on MnP of the fungal cultures: P. chrysosporium MTCC787,

Effect of MBTH concentration on MnP activity of $P$. chrysosporium:-

Kinetic studies of MnP from the fungal culture were performed against MBTH and DMAB as substrate. Km and Vmax of MnP from $P$. chrysosporium towards MBTH were reported to be $0.16 \mathrm{mM}$ and $20 \mathrm{U} / \mathrm{mg}$, respectively. 


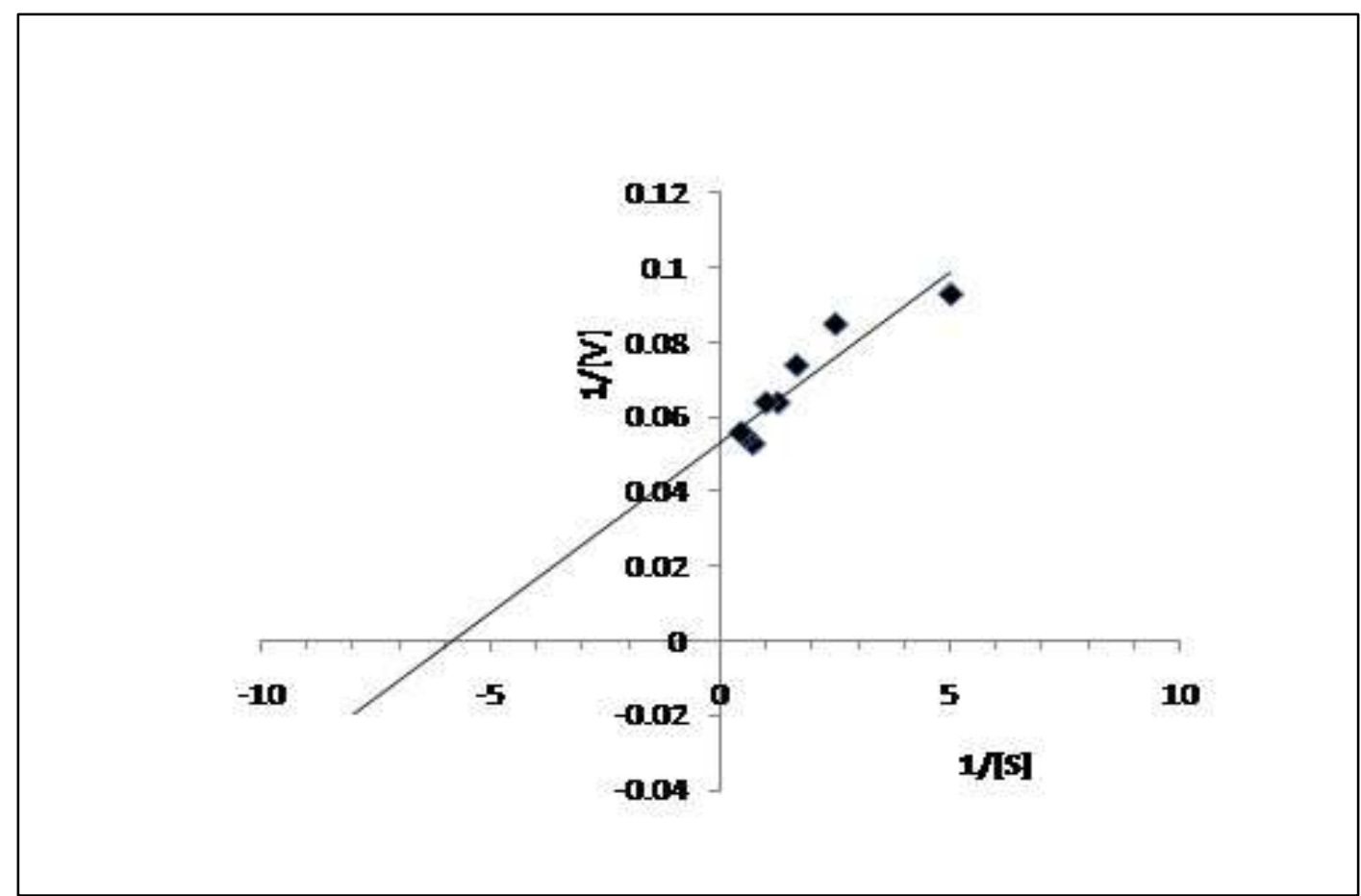

Fig 4:- LB plot of MnP from P. chrysosporium MTCC787 using MBTH-DMAB as substrate.

Effect of RBB concentration on MnP activity of $P$. chrysosporium:-

LB plot of MnP from P. chrysosporium using Reactive Black B as a substrate is shown in Fig 5 from which, the Km of $\mathrm{MnP}$ was calculated as $0.05 \mathrm{mM}$ and Vmax was reported as $25 \mathrm{U} / \mathrm{mg}$. Results indicate that RBB can be oxidatively transformed by $\mathrm{MnP}$ of the culture P. chrysosporium MTCC787.

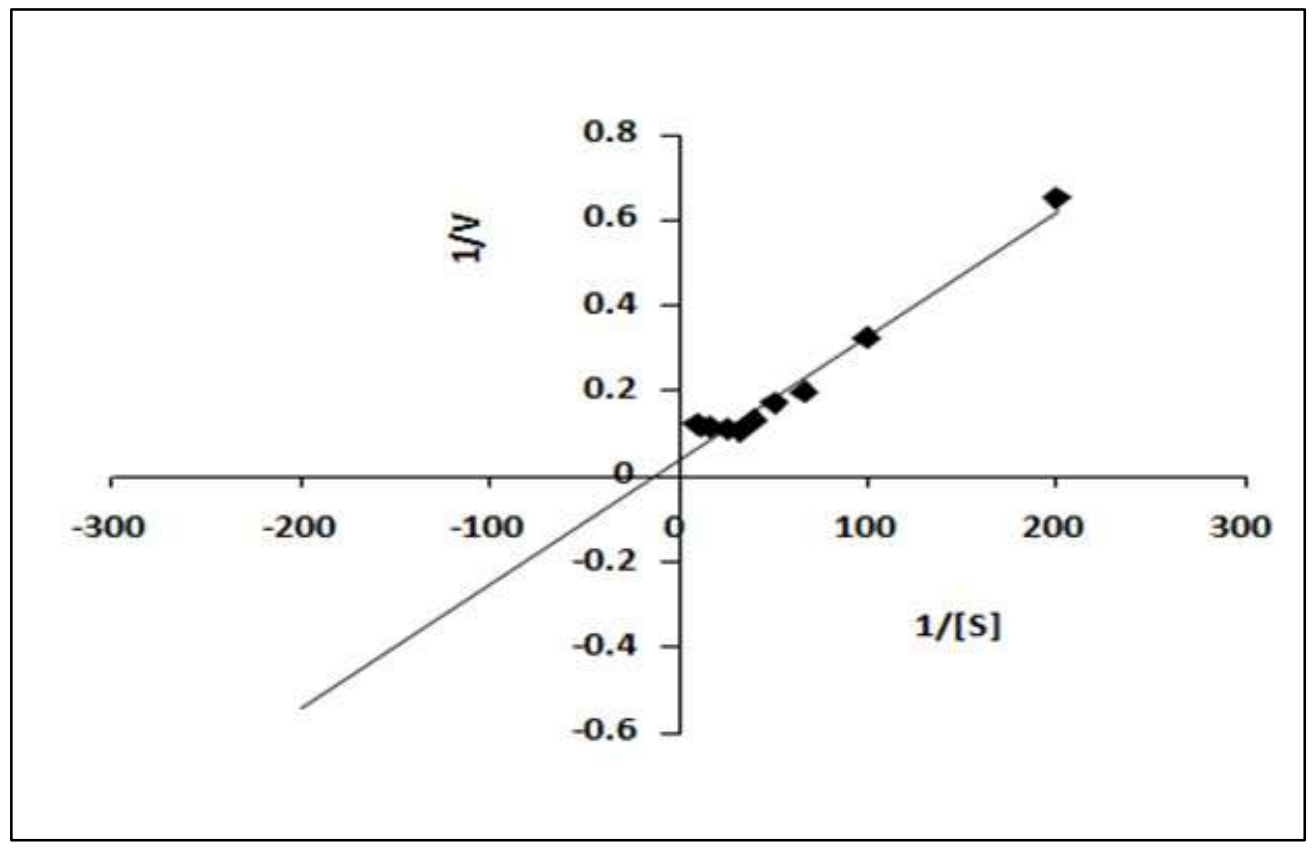

Fig 5:- LB plot of MnP from P. chrysosporium MTCC787 using Reactive Black B as substrate. 


\section{Conclusion:-}

$\mathrm{MnP}$ of $P$. chrysoporium MTCC 787 exhibited comparable characteristics with respect to $\mathrm{pH}$ and temperature optima. $\mathrm{Km}$ and Vmax of enzyme for MBTH indicates its strong affinity for the substrate. MnP kinetics were also assessed against Reactive Black B (RBB), a widely used textile diazo dye, as substrate. Here, Km and Vmax of enzyme for RBB were reported as $0.2 \mathrm{mM}$ and $7 \mathrm{U} / \mathrm{mg}$, respectively. These findings suggest enormous potential of $\mathrm{MnP}$ of $P$. chrysosporium MTCC 787 for its application in treatment of RBB containing wastewater.

\section{Acknowledgement:-}

Authors are thankful to the management of Shri M. \& N. Virani Science College, Gujarat, India; for providing research facilities.

\section{References:-}

1. Arora, D. S., Chander, M. and Gill, P. K. 2002. Involvement of lignin peroxidase, manganese peroxidase and laccase in degradation and selective ligninolysis of wheat straw, Int Biodeter and Biodeg, 50: 115.

2. Asgher M, Bhatti, H., Ashraf, M, Legge, R. 2008. Recent developments in biodegadation of industrial pollutants by white rot fungi and their enzyme system, Biodegradation;19: 771.

3. Bradford, M. M. 1976. A rapid and sensitive method for the quantitation of microgram quantities of protein utilizing the principle of protein-dye binding, Analytical Biochem, 72: 248.

4. Dellametrice, P. M., Silva-Stenico, M. E., Beraldo de Moraes, L. A., Flore, M. F., Monteiro, R. T. R. (2017): Degradation of textile dyes by cyanobacteria, Braz J Microbiol, 48: 25-31.

5. Ghodake, G. S, Kalme, S. D., Jadhav, J. P. and Govindwarv S. P. 2009. Purification and partial characterization of lignin peroxidase from Acinetobacter calcoaceticus NCIM 2890 and its application in decolorization of textile dyes. Appl Biochem Biotechnol, 152: 6-14.

6. Junnarkar, N., Murty, D. S., Bhatt, N. S. \& Madamwar, D. (2006): Decolorization of diazo dye Direct Red 81 by a novel bacterial consortium. World J of Microbiol Biotechnol. 22: 163-168.

7. Junnarkar, N., Pandhi, N., Raiyani, N., Bhatt, N. and Raiyani, R. (2016): Production of LiP by Phanerochaete chrysosporium MTCC 787 through Solid State Fermentation of Wheat Straw and assessing its activity against Reactive Black B, Int J Adv Res, 4: 812-819.

8. Kerem, Z., Friesem,D. and Hadar,Y. 1992. Lignocellulosic degradation during solid state fermentation: Pleurotus ostreatus versus Phanerochaete chrysosporium, App Env Microbiol, 58: 1121-1127.

9. Moldes, D., Couto, R. S., Cameselle, C. and Sanroman, M. A. 2003. Study of the degradation of dyes by MnP of Phanerochaete chrysosporium produced in a fixed-bed bioreactor, Chemosphere, 51: 295-303.

10. Saratale, R.G., Saratale, G.D., Chang, J.S., Govindwar, S.P., 2009. Decolorization and biodegradation of textile dye Navy blue HER by Trichosporon beigelii NCIM- 3326, J Haz Mat, 166: 1421-1428.

11. Saratale, R. G., G.D. Saratale, J.S. Chang, S. P. Govindwar 2011. Bacterial decolorization and degradation of azo dyes: A review, J Taiwan Inst Chem Eng, 42: 138-157.

12. Sklener, J., Santos, S., Man, P., Kruus, K., Novotny, C. (2010): Isolation and characterization of novel pI 4.8 MnP isoenzyme from white-rot fungus Irpex lacteus, Enzyme Microb Technol, 7: 550-556.

13. Wesenberg, D., Kyriakides, I. and Agathos S. N. 2003. White-rot fungi and their enzymes for the treatment of industrial dye effluents, Biotechnol Adv, 22: 161-187.

14. Zeng, G., Zhao, H., Huang, D., Lai, C., Huang, C., Wei, Z., Xu, P., Li, N., Zhang, C., Li, F., Cheng, M. 2013. Purification and biochemical characterization of two extracellular peroxidases from Phanerochaete chrysosporium responsible for lignin biodegradation, Int Biodeter Biodegr, 85: 166-172.

15. Zeng, G., Cheng, M., Huang, D., Lai, C., Xu, P., Wei, Z., Li, N., Zhang, C., He, X. and He, Y. 2015. Study of the degradation of methylene blue by semi-solid-state fermentation of agricultural residues with Phanerochaete chrysosporium and reutilization of fermented residues, Waste Manag, 38: 424-430. 